\title{
Simulation of Inconel 718 alloy machining with respect to the modified material model
}

\author{
Symulacja obróbki stopu Inconel 718 w odniesieniu \\ do zmodyfikowanego modelu materiałowego
}

WOJCIECH ZĘBALA *

DOI: 10.17814/mechanik.2016.5-6.70

Międzynarodowa Konferencja IMT 2016

\begin{abstract}
The paper presents simulation researches of the aeroplane part machining. A simulation model of Inconel 718 alloy machining based on the Lagrangian formulation contains the Johnson-Cook material model. The dependence of simulation results from the material model formulations (plastic strain, strain rate and temperature) was presented.

KEYWORDS: simulation of machining, Inconel 718, material model
\end{abstract}

W artykule przedstawiono badania symulacyjne obróbki części lotniczej. Model symulacyjny skrawania stopu Inconel 718, zbudowany w oparciu o sformułowania Lagrange'a, zawiera model materiałowy Johnsona-Cooka. Zaprezentowano zależność wyników obliczeń symulacyjnych od charakterystyk modelu materiałowego, opisujących odkształcenie plastyczne, prędkość odkształcenia i temperaturę.

SŁOWA KLUCZOWE: symulacja obróbki, Inconel 718, model materiałowy

Modern metal constructions, especially in aerospace industry demand a basic understanding of the mechanical behaviour of materials $[1 \div 4]$. The modelling of metal cutting has proved to be particularly complex due to the diversity of physical phenomena involved, including thermo-mechanical coupling, contact/friction and material failure [5]. Through the use of simulation technologies, the properties of the materials are intensively considered [6]. The complex properties of metal alloys structures present significant challenges during manufacturing processes. For this reason, the proper material model applied in the simulation procedure of machining is an essential tool to analyse the complex behaviour of materials under the high loads, high temperature and quick changes of loads.

This paper presents simulation researches of the aeroplane part surface turning. The engine block unit of cylindrical shape and small wall thickness was applied in the simulation procedure.

\section{Modeling of machining}

Numerical simulations of cutting process were performed according to a Lagrangian FE code [7] for a time necessary to achieve the steady-state phase of chip creation. Techniques such as adaptive remeshing and thermal analysis were integrated to model the complex interactions of the tool wedge and workpiece. The workpiece material, Inconel 718 $(0.4 \% \mathrm{Al} ; 0.04 \% \mathrm{C} ; 19 \% \mathrm{Cr} ; 18.5 \% \mathrm{Fe} ; 3 \% \mathrm{Mo} ; 0.9 \% \mathrm{Ti})$, was modeled as thermo-elastic-plastic, while the flow stress was considered to be a function of strain, strain-rate and temperature. Two material models were compared in the

\footnotetext{
* Prof. dr hab. inż. Wojciech Zębala (zebala@mech.pk.edu.pl) Instytut Technologii Maszyn i Automatyzacji Produkcji - M6, Wydział Mechaniczny, Politechnika Krakowska
}

researches. The first constitutive model was a modified Johnson-Cook model [7]. The equivalent stress is defined in Equation. The table presents the main model parameters.

$$
\sigma(\alpha, \dot{\alpha}, T)=\left(A+B \alpha^{n}\right)\left(1+\operatorname{cln}\left(\frac{\dot{\alpha}}{\dot{\alpha_{0}}}\right)\right)\left(1-\left(\frac{T-T_{\text {room }}}{T_{\text {melt }}-T_{\text {room }}}\right)^{m}\right.
$$

where: $A$ is the yield stress, $B$ is the strain hardening coefficient, $c$ is the strain rate dependence coefficient, $n$ is the strain hardening exponent and $m$ is the temperature dependence coefficient material parameters. $T_{\text {melt }}$ is the melting temperature for the material, $\dot{\alpha}$ is an equivalent plastic strain rate and $\dot{\alpha}_{0}$ is the reference strain rate.

TABLE. Material constants of the modified J-C flow stress model for Inconel 718 alloy

\begin{tabular}{|c|c|c|c|c|c|}
\hline$A, \mathrm{MPa}$ & $B, \mathrm{MPa}$ & $n$ & $c$ & $m$ & $T_{\text {melt, }}{ }^{\circ} \mathrm{C}$ \\
\hline $1.012 \mathrm{E} 9$ & $3.93 \mathrm{E} 8$ & 0.125 & 0.027 & 2.42 & 1277 \\
\hline
\end{tabular}

In case of second material model, physical and mechanical properties of Inconel 718 were used in simulation according to the standard data implemented in the software [8], named a standard model in the next part of the paper.

Calculations were performed for the roughing and finishing operations. For roughing operations a sialon insert RNGN120700T01020 was used. Cutting parameters used in turning were as follows: $v_{c}=200 \mathrm{~m} / \mathrm{min}$, feed $f=0.15 \mathrm{~mm} / \mathrm{rev}$. For finishing turning cutting data were as follows: $v_{c}=160 \mathrm{~m} / \mathrm{min}, f=0.13 \mathrm{~mm} / \mathrm{rev}$. Fig. 1 shows the geometry of semi-finished part and tool paths for turning operations.

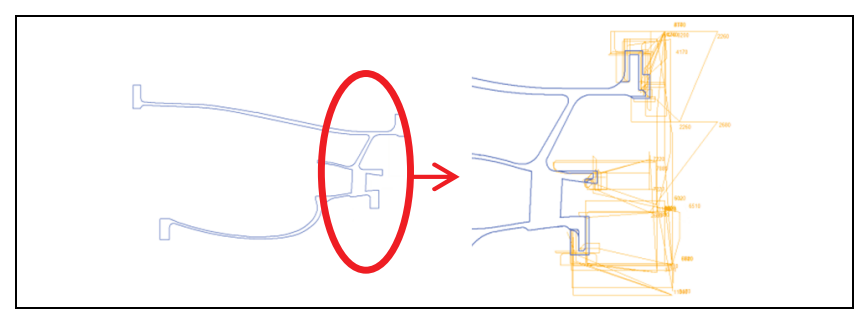

Fig. 1. Engine block unit with tool paths for turning operations

The simulation of the engine block unit machining was performed on the CNC machining center. Due to the thin wall nature of the workpiece, as a result of cutting forces influence, geometric deformation can take place which leads to incorrect execution of machined surfaces. During thinwalled parts machining, the value levels of the components of resultant cutting force plays the important role.

In the first stage of research a simulation of chip forming in the decohesion zone was performed. The comparison of example results of numerical calculations of temperature and stress-XX component field distributions for modified (1) and standard (2) material models are presented in Fig. $2 \div 5$. 
It can be noticed that chip shape as well as temperature and stress fields distributions are different.

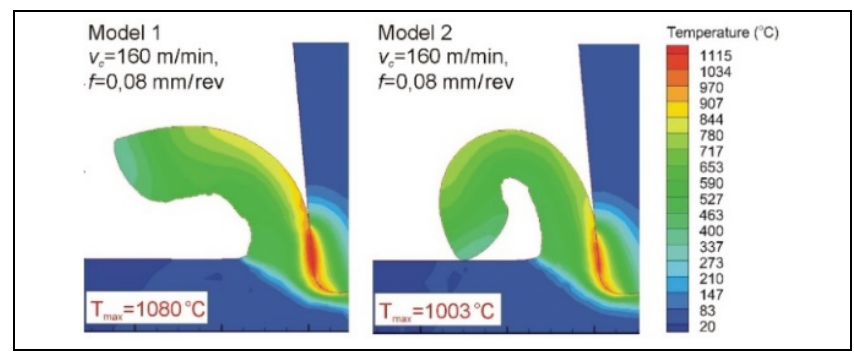

Fig. 2. Comparison of temperature field distribution for modified (1) and standard (2) material models. Cutting data: $v_{c}=160 \mathrm{~m} / \mathrm{min}$, $f=0.08 \mathrm{~mm} / \mathrm{rev}, a_{p}=1 \mathrm{~mm}$

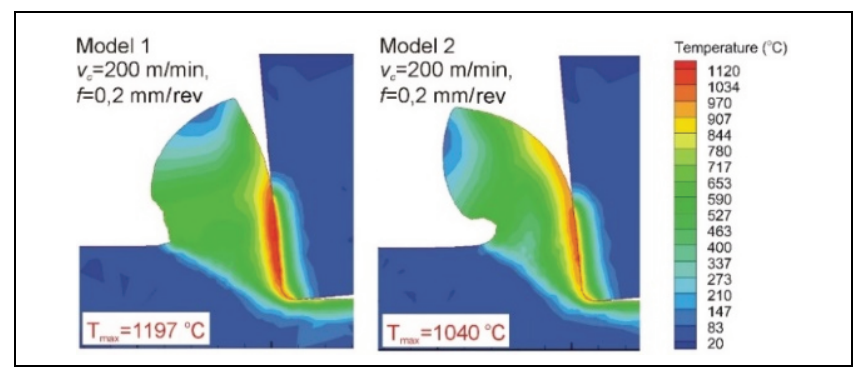

Fig. 3. Comparison of temperature field distribution for modified (1) and standard (2) material models. Cutting data: $v_{c}=200 \mathrm{~m} / \mathrm{min}$, $f=0.2 \mathrm{~mm} / \mathrm{rev}, a_{p}=1 \mathrm{~mm}$

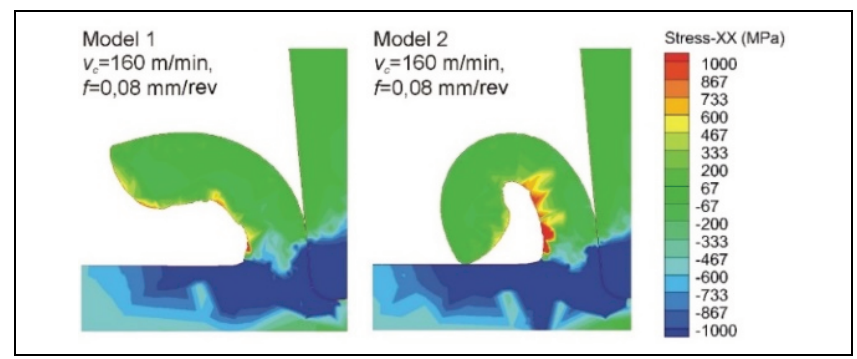

Fig. 4. Comparison of stress- $X X$ component field distribution for modified (1) and standard (2) material models. Cutting data: $v_{c}=160 \mathrm{~m} / \mathrm{min}, f=0.08 \mathrm{~mm} / \mathrm{rev}, a_{p}=1 \mathrm{~mm}$

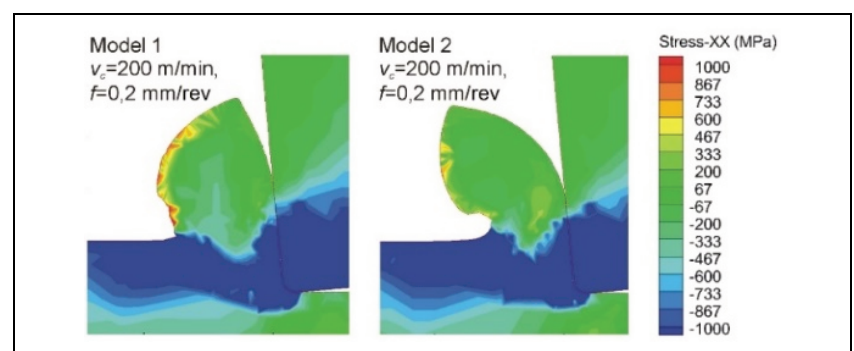

Fig. 5. Comparison of stress- $X X$ component field distribution for modified (1) and standard (2) material models. Cutting data: $v_{c}=200 \mathrm{~m} / \mathrm{min}, f=0.2 \mathrm{~mm} / \mathrm{rev}, a_{p}=1 \mathrm{~mm}$

In the next research phase a physics-based NC program optimization software Production Module [9] was applied. The tool work along the entire tool path was simulated, according to Fig. 1.

The time course of the tangential cutting force component and chip thickness during turning for modified (1) and standard (2) material models are presented in Fig. 6 and 7, respectively. The calculated force values differ for the two models in the range of $12-18 \%$. The differences of the chip thickness are smaller, max. $5 \%$.

The built force model allows to calculate the cutting forces values, depending on the cutting parameters and material properties, and then optimize the machining process through the changes of the cutting data, e.g. feed speed.

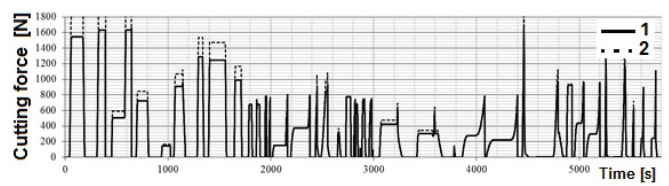

Fig. 6 . The time course of the tangential cutting force component during turning along the entire tool path for modified (1) and standard (2) material models

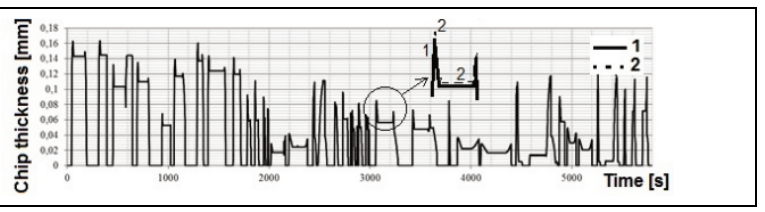

Fig. 7. The time course of the chip thickness during turning along the entire tool path for modified (1) and standard (2) material models

\section{Conclusions}

Based on the experience in machining and the use of modern software and hardware, it is possible to simulate machining operations precisely in condition that we are able to prepare the correct material model. Otherwise, the calculation results will be inaccurate. The simulation research shown that temperature and cutting force have higher values for the standard material model than for modified one, which translates into further optimization cutting data.

After initial analysis of the force value during machining operations it is possible to change cutting parameters (e.g. feed speed) to increase productivity, tool life or shorten cutting time. It is also necessary to monitor simultaneously the influence of proposed changes on the shape and dimensional accuracy, roughness of machined surfaces and the stability of Machine tool - Tool - Holder - Workpiece (MTHW) configuration.

A financial support of The National Centre for Research and Development Project No. INNOLOT///9/NCBR/2013 "Advanced methods for manufacturing of aero engine case module components" is gratefully acknowledged.

\section{LITERATURE}

1. Ulutan D., Ozel T. „Machining induced surface integrity in titanium and nickel alloys: A review". International Journal of Machine

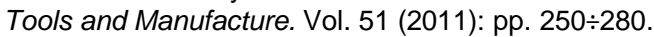

2. Dudzinski D., Devillez A., Moufki A., Larrouque're D., Zerrouki V., Vigneau J. „A review of developments towards dry and high speed machining of Inconel 718 alloy". International Journal of Machine Tools and Manufacture. Vol. 44, No. 4 (2004): pp. $439 \div 456$.

3. Eckstein M., Mankova I., Vrabel M., Beno J. „Comparison of Sensors Signal Quality when Drilling Inconel "718". Procedia

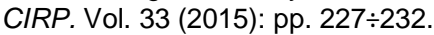

4. Jaspers S.P.F.C., Dautzenberg J.H. „Material behavior in conditions similar to metal cutting: flow stress in the primary shear zone". Journal of Materials Processing Technology. Vol. 122, No. 2-3 (2002): pp. 322 $\div 330$.

5. Vaz Jr. M., Owen D.R.J., Kalhori V., Lundblad M., Lindgren L.-E. „Modelling and Simulation of Machining Processes”. Archives of Computational Methods in Engineering. Vol. 14, No. 2 (2007): pp. $173 \div 204$.

6. Choudhary S.K., Rao Appa I.V.K. „Optimization of cutting parameters for maximizing tool life". International Journal of Machine Tools and Manufacture. Vol. 39, No. 2 (1999): pp. $343 \div 353$.

7. Marusich T.D., Ortiz M. „Modelling and Simulation of High-Speed Machining". International Journal for Numerical Methods in Eng-

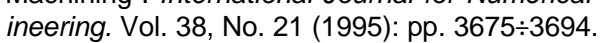

8. User's Manual of AdvantEdge v7.1 machining simulation software. Minneapolis: MN, 2015.

9. User's Manual of Production Module v7.1 machining simulation software. Minneapolis: MN, 2015. 